\title{
REVERSE TRANSCRIPTIONAND POLYMERASE CHAIN REACTION: PRINCIPLES AND APPLICATIONS IN DENTISTRY
}

\author{
TRANSCRIÇÃO REVERSA E REAÇÃO EM CADEIA DA POLIMERASE: \\ PRINCÍPIOS E APLICAÇÕES EM ODONTOLOGIA
}

\author{
Carlos Ferreira dos SANTOS, DDS, PhD \\ Assistant Professor, Bauru School of Dentistry, University of São Paulo, Brazil. \\ Vivien Thiemy SAKAI, DDS \\ Graduate Student, Bauru School of Dentistry, University of São Paulo, Brazil. \\ Maria Aparecida de Andrade Moreira MACHADO, DDS, PhD \\ Associate Professor, Bauru School of Dentistry, University of São Paulo, Brazil. \\ Daniela Nicole SCHIPPERS \\ Medical College of Wisconsin, Department of Physiology, Milwaukee, USA.
}

Andrew Seth GREENE, PhD

Professor, Medical College of Wisconsin, Department of Physiology and Biotechnology and Bioengineering Center, Milwaukee, USA.

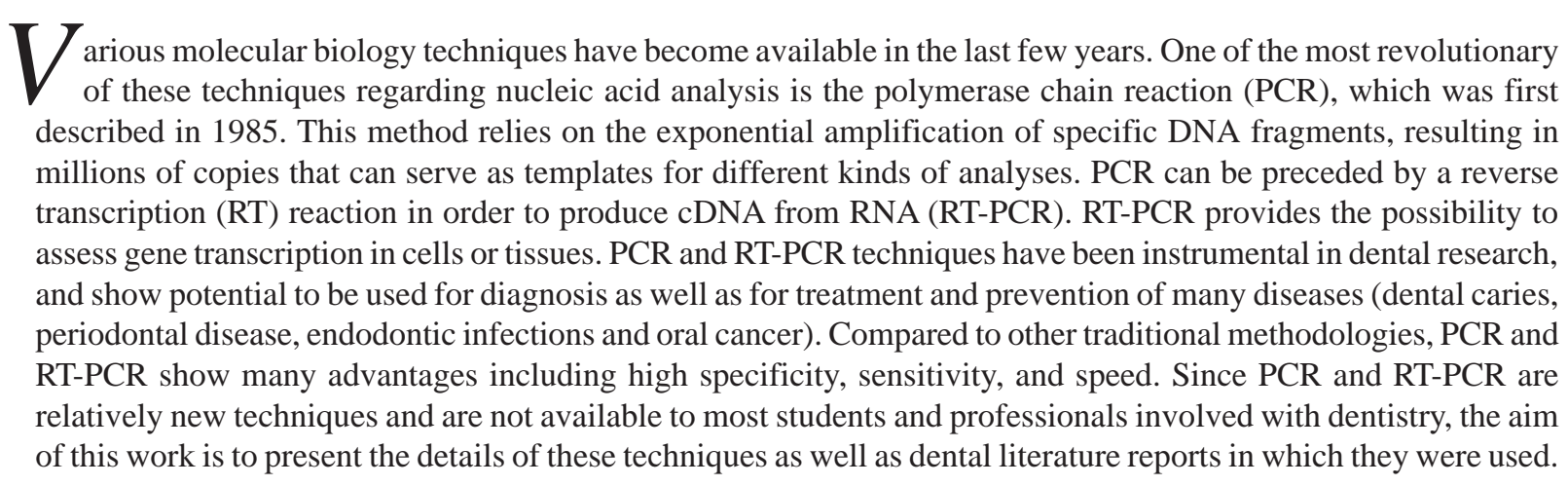

UNITERMS: Dental caries; Periodontitis; Dental pulp disease; Oral cancer.

\section{INTRODUCTION}

The field of human genetics was revolutionized when Watson and Crick described the structure of DNA as a double helix in 1953, 74 years after the first DNA isolation by Johann Friedrich Miescher. Recognition of the universality of the genetic code in living organisms has been essential to the development and application of genetic technologies ${ }^{13,19}$.

Several methods have been employed in dentistry to better understand and diagnose infectious agents leading to maxillofacial infections, and consequently to achieve the patient risk assessment for caries, periodontal disease and other oral disease development ${ }^{21}$. These include culture methods, microscopy, immunofluorescent assays, enzyme- linked immunosorbent assays and DNA probes. More recently the polymerase chain reaction (PCR) was introduced. PCR is a highly sensitive and specific technique by which minute quantities of specific DNA (or RNA after reverse transcription - RT-PCR) can be enzymatically amplified $^{8,14-18,22,26,29,32-36,38,39,42,44,45,47-49,57-59}$. These techniques can be used to detect very small amounts of bacterial, fungal, or viral nucleic acid in clinical specimens ${ }^{2,3,5,6,22,28,29,37,53}$. Many different types of clinical samples have been used for PCR analysis, including blood, sputum, semen, single hairs and saliva $^{19}$. Saliva is a potential source of material for diagnostic testing in both systemic and oral disease. With new interest in the link between oral and systemic health and recent success using saliva-based molecular diagnostics, it is 
possible that saliva sampling may become part of the routine examination and assessment of dental patients. In addition to being a site where the biologically active proteins and exogenous substances such as drugs can be found, saliva is also a source of DNA from patients ${ }^{29,30,42,47-49,59}$ and from cariogenic and periodontopathogenic microorganisms $\mathrm{s}^{8,14-}$ 18,22,26,29,32-36,38,39,42,44,45,47-49,57-59

The purpose of this work is to present the details of PCR and RT-PCR in an attempt to clarify the principles and applications of both techniques in Dentistry.

\section{PCRAND RT-PCR DESCRIPTION}

\section{Polymerase chain reaction (PCR)}

PCR is the enzymatic amplification of a specific DNA sequence in vitro ${ }^{9}$. This process uses multiple cycles of template denaturation, primer annealing, and primer elongation to amplify DNA sequences. It is an exponential process since the amplified products from each previous cycle serve as templates for the next cycle of amplification, thus making it a highly sensitive technique for the detection of specific nucleic acids sequences. Typically, enough amplified product is generated after 20 to 40 cycles of PCR, so that it can be visualized on an ethidium bromide-stained gel. The reaction includes several components: template, forward primer, reverse primer, reaction buffer, magnesium, dNTP mix, and thermostable DNA polymerase. The template can include purified genomic or plasmid DNA; RNA converted by reverse transcriptase to complementary DNA (cDNA); or unpurified, crude biological samples such as bacterial colonies or phage plaques. The forward and reverse primers determine the sequence and the length of the amplified product. The most frequently used thermostable polymerase is Taq DNA polymerase. This enzyme is appropriate for routine amplifications, but the use of other thermostable polymerases can enhance results. The magnesium ion concentration affects enzyme activity, primer annealing, melting temperature of the template and the PCR product, fidelity, and primer-dimer formation ${ }^{19,40}$.

PCR explores the replicating capacity of DNA. A single DNA strand is used as template for the synthesis of new complementary chains under the action of DNA polymerase enzyme, which is able to bind the nucleotides present in reaction to the template. However, DNA polymerase requires a starting point in the template, which will direct the addition of subsequent nucleotides. This synthesis starting point is provided by an oligonucleotide that hybridizes (anneals) itself to the single template strand; this oligonucleotide is called a primer ${ }^{46}$. Both original strands of DNA act as template to the synthesis, once specific primers are provided to each one. Thus, the region of DNA to be synthesized is defined by the primers, which specifically anneal themselves to their complementary sequences on template strand, limiting the DNA fragment that will be amplified ${ }^{9,46}$.

Once started with a suitable primer, a polymerase enzyme will copy a DNA strand starting from the 3' end of the primer and synthesizing new DNA in a 5' to 3' direction - the extension step. DNA extension is halted by raising the temperature (usually to $94^{\circ} \mathrm{C}$ ), causing separation of all DNA strands. Cooling to temperatures of $37-60^{\circ} \mathrm{C}$ causes annealing of the primer and DNA template. Raising the temperature again (typically to $72^{\circ} \mathrm{C}$ ) stimulates the heatstable Taq polymerase to copy the DNA template in a further extension step. Thus, each cycle contains three steps annealing of primers to the DNA template, extension of the DNA, and strand separation ${ }^{46,62}$. If two primers are added, one complementary to each strand, there is an exponential increase in copies of the DNA enclosed by the two primers for each cycles: $1,2,4,8,16,32$, etc.; an increase of $2^{n}$, where $\mathrm{n}$ is the number of cycles. This is because each primer can direct synthesis along the copy made by the other primer, as well as along its own original template ${ }^{62}$ (Figure 1).

After amplification, the products are size-fractionated by electrophoresis on an agarose or polyacrylamide gel stained with ethidium bromide. Products appear as a single band corresponding to the size of the amplified sequence, which fluoresces when illuminated with ultraviolet light (Figure 2).

Generally speaking, PCR can be used to detect and amplify nucleic acid from anywhere, regardless of quantity and combination, since only a limited starting quantity is needed for amplification ${ }^{40}$.

In this way, PCR is used in detection assays for infectious agents, pre-natal diagnosis of genetic disease, genomic DNA or cDNA cloning, rare RNA quantification, RNA amplification by RT-PCR, in vitro mutagenesis and recombinant DNA manufacture, studies of forensic samples, and variation analysis of alleles sequences.

\section{Reverse transcription- polymerase chain reaction (RT-PCR)}

The starting template for a PCR reaction can be DNA or RNA. DNA is usually the appropriate template for studying the genome of the cell or tissue (as in inherited genetic diseases, somatic mutation in a tumor, or somatic rearrangement in lymphocytes) and for the detection of DNA viruses $^{62}$.

For information on gene expression in a cell ${ }^{60}$ or tissue $^{11,12,31,50,51}$, or the presence of genomic RNA in a retrovirus such as HIV, RNA is the appropriate template. RNA can be better than genomic DNA for detecting structural changes in long genes, since amplifying the spliced RNA transcript instead of the genomic sequence greatly reduces the length of DNA to be handled without losing any of the coding regions where clinically significant deletions may be expected ${ }^{62}$.

RT-PCR combines cDNA synthesis from RNA templates with PCR to provide a rapid, sensitive method for analyzing gene expression (Figure 3). RT-PCR is used to detect or quantify the expression of mRNA, often from a small concentration of target RNA $25,50,51$.

The template for RT-PCR can be total RNA or poly (A) ${ }^{+}$ selected RNA. RT reactions can be primed with random 
primers, oligo(dT), or a gene-specific primer (GSP) using a reverse transcriptase. RT-PCR can be carried out either in two-step or one-step formats. In two-step RT-PCR, each step is performed under optimal conditions. cDNA synthesis is performed first in RT buffer and one tenth of the reaction is removed for PCR ${ }^{50,51}$. In one-step RT-PCR, reverse transcription and PCR take place sequentially in a single tube under conditions optimized for both RT and PCR ${ }^{40}$.

\section{LITERATURE REVIEW}

In 1985, PCR, arguably one of the most important techniques in molecular biology, was introduced by Saiki et $\mathrm{al}^{46}$. They developed a procedure for the detection of the sickle cell mutation that is very rapid and is at least two orders of magnitude more sensitive than standard Southern blotting. They also suggested that the ability of the PCR procedure to amplify a target DNA segment in genomic DNA might extend its use beyond that of prenatal diagnosis to other areas of molecular biology ${ }^{46}$.

From the PCR technique publication on, there has been
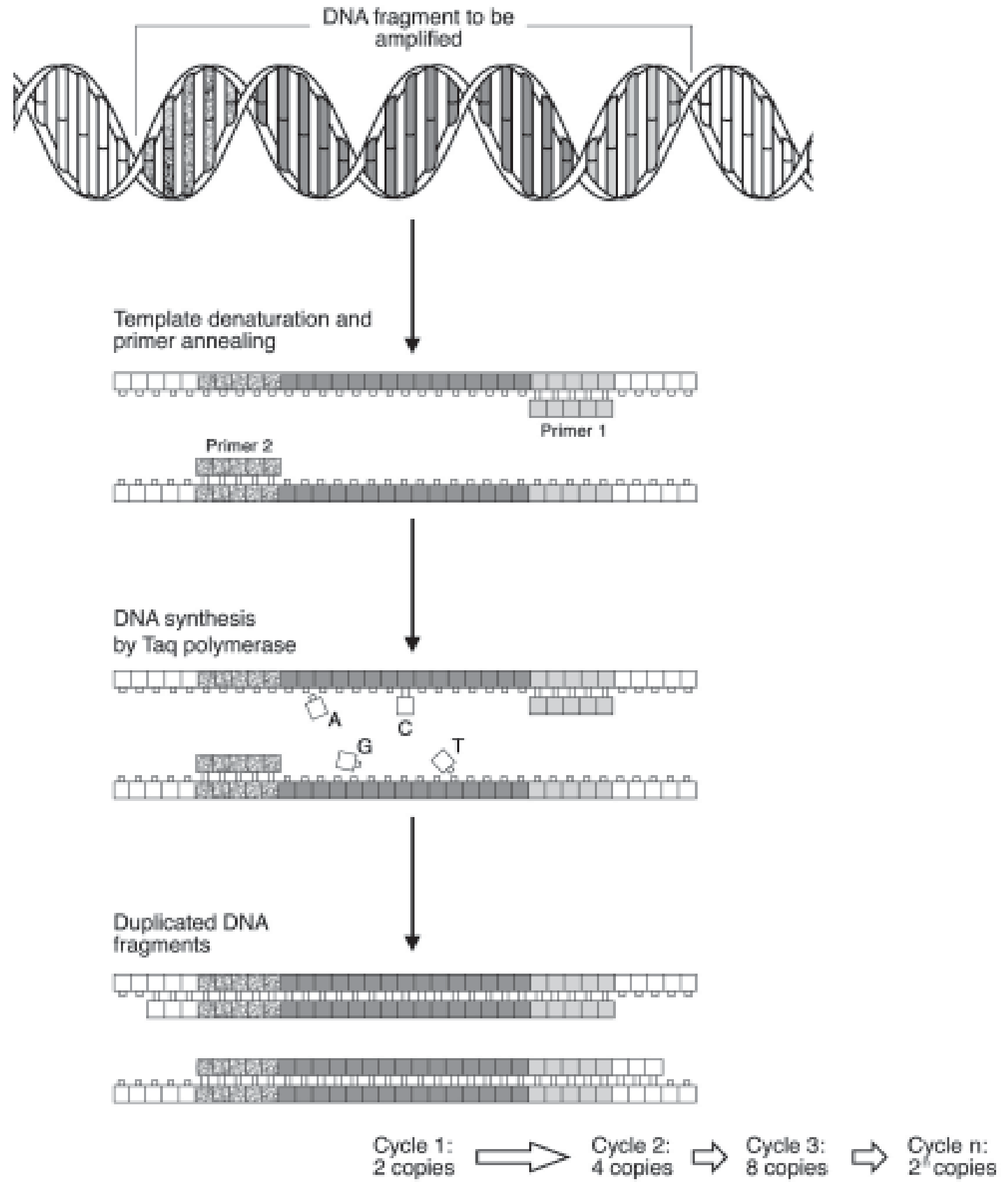

FIGURE 1- Schematic diagram of PCR showing that each cycle contains three steps (annealing of primers to the DNA template, extension of the DNA and DNA denaturation), and illustrating the exponential nature of the reaction (Modified from $\operatorname{Farah}^{9}$ ). 
an explosion of its utilization in medicine and science. More recently, it has become useful as a diagnostic technique and as a research tool in dentistry. As follows, dental literature reports in which PCR or RT-PCR were used for the study of factors involved in periodontal disease, dental caries, endodontic infections and oral cancer are reviewed.

\section{Periodontal disease}

To begin to elucidate on a possible involvement of human viruses in periodontal disease, Parra and Slots ${ }^{37}$, in 1996, determined the prevalence of human cytomegalovirus (HCMV), Epstein-Barr virus type 1 and 2 (EBV-1 and -2), herpes simplex virus, human papillomavirus and HIV in

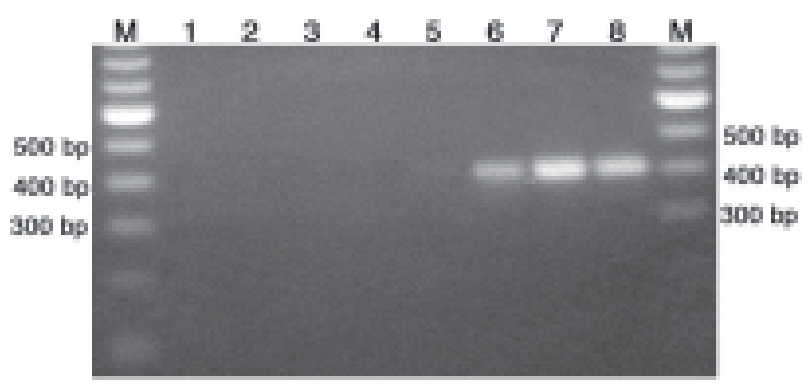

FIGURE 2- Ethidium bromide-stained agarose gel showing results of $\mathrm{PCR}$ amplification. A single DNA band of the predicted size (404 bp) was obtained using specific primers against the target organism Porphyromonas gingivalis. DNA was extracted from different human saliva samples. M, 100-bp markers; Lane 1, negative control; Lanes 2-5, samples not showing target DNA amplification; Lanes 6 and 7, samples showing target DNA amplification; Lane 8, positive control. crevicular fluid from individuals with various forms of periodontal disease. Viral identification was performed using a PCR-based technique. This study provided evidence of human viruses in the crevicular fluid of many advanced adult periodontitis lesions. Saygun, et al. ${ }^{52}$, in 2002, confirmed the frequent presence of HCMV in crevicular samples of chronic periodontitis lesions, and suggested a strong relationship between the presence of HCMV and EBV-1 in subgingival areas and the measurements of probing depth and probing attachment loss.

In order to study the role of chemokines in periodontal diseases, Garlet, et al. ${ }^{11}$, in 2003, examined the expression of chemokines, chemokine receptors and cytokines characteristic of Th patterns of immune response in gingival biopsies from aggressive periodontitis and chronic periodontitis patients by means of reverse transcriptionpolymerase chain reaction (RT-PCR) techniques. The expression of the chemokines macrophage inflammatory protein-1 alpha and interferon-gamma inducible protein 10 and of their respective receptors, CCR5 and CXCR3, were more prevalent and higher in aggressive periodontitis. In addition, these patients also showed higher interferongamma expression and lower interleukin-10 expression. In contrast, chronic periodontitis patients exhibited a more frequent and higher expression of monocyte chemoattractant protein-1 and its receptor CCR4, and higher expression of IL-10.

Shelburne, et al. ${ }^{53}$, in 2002, to explore expression of Porphyromonas gingivalis virulence factors in periodontitis subjects, modified methods for quantitative measurement of gene activation. They found quantitative (real time) reverse transcription PCR (QRT-PCR) well suited to examine gene expression of the oral anaerobe $P$. gingivalis in periodontal disease in vivo, and they also described their first results with QRT-PCR using a selection of putative virulence factors. The efficacy of PCR method for detection of $P$. gingivalis from salivary samples was compared with

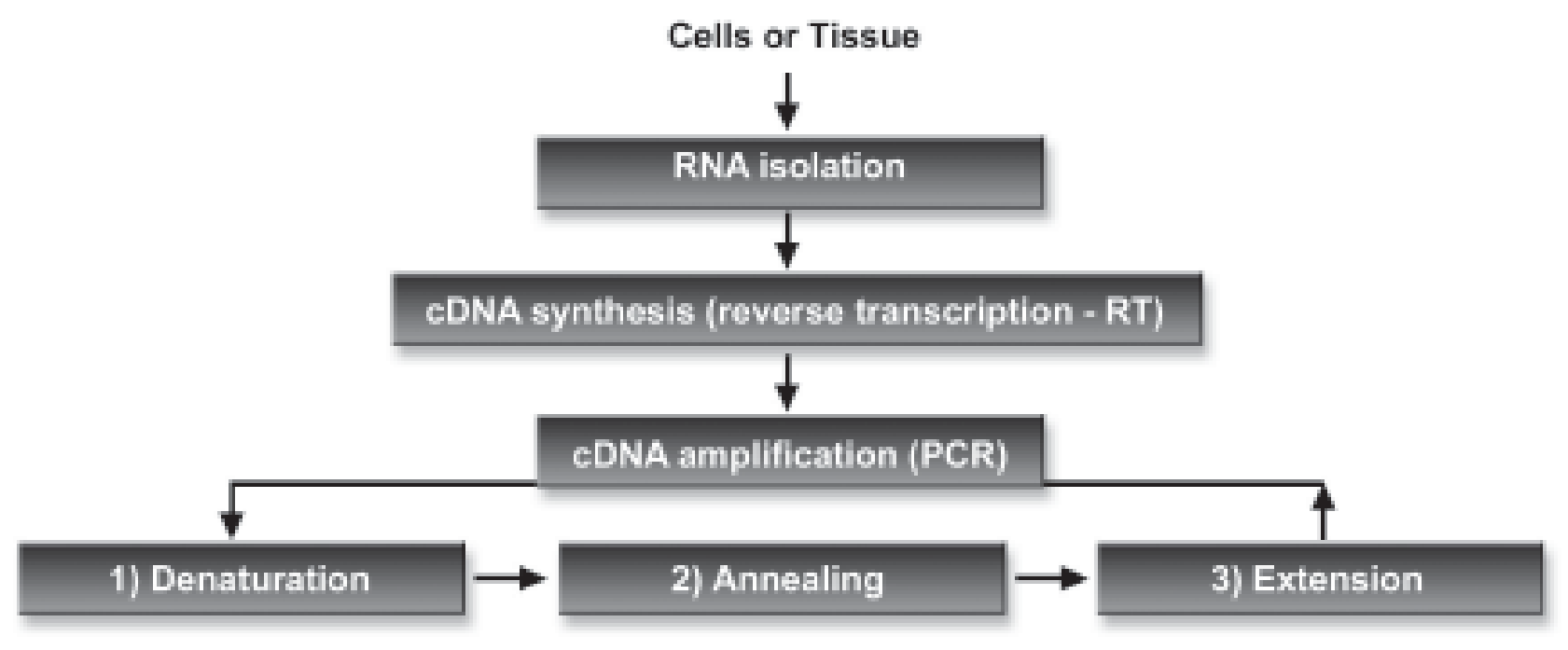

FIGURE 3- Schematic diagram of RT-PCR showing that RNA isolated from cells or tissue is used as substrate in reverse transcription for synthesis of cDNA that will serve as template for amplification by PCR. 
that of bacterial culture by Mättö, et al. ${ }^{29}$, in 1998. The authors showed that this bacteria was detected in saliva three times more often by PCR than by culture.

PCR technique was also used by Sakamoto, et al. ${ }^{48}$, in 1999, for the detection and identification of Treponema socranskii associated with periodontal disease. Pathogen frequency correlated with increasing gingival index scores in both children and adults. T. socranskii was detected more often in subgingival plaque samples than in saliva samples.

Okada, Hayashi, Nagasaka ${ }^{35}$, in 2000, aimed to detect the presence of Actinobacillus actinomycetemcomitans and $P$. gingivalis in plaque samples from children, collected from their toothbrushes using PCR. This survey indicated that A. actinomycetemcomitans and $P$. gingivalis are rarely present in oral cavities of healthy children.

Hayashi, et al. ${ }^{14}$, in 2001, accomplished a study whose purpose was to detect the presence of Capnocytophaga sputibena, C. ochracea and C. gingivalis, using PCR, in plaque samples taken with a toothbrush from children. This survey indicated that $C$. sputigena had a moderate prevalence, whereas $C$. ochracea and $C$. gingivalis were commonly detected in the oral cavities of children, suggesting that these three species become established in the early years. Using the same methodology, Okada, Hayashi, Nagasaka ${ }^{36}$, in 2001, assessed the presence of Prevotella intermedia, Prevotella nigrescens, Bacteroides forsythus, Treponema denticola and Campylobacter rectus. The study indicated that $P$. intermedia and $T$. denticola were more associated with periodontal disease, $B$. forsythus and $P$. nigrescens had a moderate prevalence in all clinical groups, while $C$. rectus were the most commonly detected species in the oral cavities of children also suggesting establishment in their early years.

Other bacteria studied by Takeuchi, et al. ${ }^{59}$, in 2001, were T. socranskii, $T$. denticola e $P$. gingivalis. They aimed to identify these microorganisms by PCR, and to clarify the relationship between their presence and the severity of clinical periodontal parameters such as bleeding on probing, probing depth and gingival index. So, T. socranskii, $T$. denticola and $P$. gingivalis were identified by PCR in plaque and saliva samples, and it was found that the presence of $T$. socranskii was associated with periodontitis. T. socranskii was more frequently detected in plaque samples from aggressive or chronic periodontitis patients than from healthy subjects. The detection frequency of T. socranskii was elevated at sites where severe periodontal tissue destruction was observed. The prevalence of these 3 microorganisms was correlated with various clinical parameters. The data suggested that their presence was associated with the severity of periodontal tissue destruction.

In 2002, Kimura, et al. ${ }^{22}$ carried out a cross-sectional study to assess the prevalence and distribution of putative bacteria in 144 children ( 2 to 13 years old, 12 subjects from each year of age) who showed no or negligible periodontal inflammation. This study used a PCR assay with speciesspecific primer for 10 putative periodontopathogenic bacteria: $P$. gingivalis, $B$. forsythus, $P$. intermedia, $P$. nigrescens, C. rectus, E. corrodens, A. actinomycetemcomitans, C. ochracea, C. sputigena and $T$. denticula. A subject-based analysis of bacterial infection indicated that the number of bacterial species in plaque samples had increased gradually by age in this study, and further suggested that E. corrodens, $A$. actinomycetemcomitans, C. ochracea, $C$. sputigena and $C$. rectus could be early colonizers of dental plaque. Moreover, no positive association for bacterial combinations in colonization was found in this study of periodontally healthy children.

Doungudomdacha, Rawlinson, Douglas ${ }^{8}$, in 2000, developed a sensitive quantitative-competitive PCR (QCPCR) technique for the identification of $P$. gingivalis, $P$. intermedia and A. actinomycetemcomitans, in either laboratory strains or subgingival plaque samples, with specific primers for the fimA gene, the 16S rRNA gene and the $l k t A$ gene, respectively. This method proved to be rapid, reproducible and extremely sensitive; the primers employed were highly specific and capable of differentiating the target organisms from a number of closely related cultivable species.

Real-time PCR offers a sensitive, efficient, and reliable approach to quantitation. Using the TaqMan system, Lyons, Griffen, Leys ${ }^{26}$, in 2000, were able to determine both the amount of $P$. gingivalis and the total number of bacteria present in plaque samples directly without culturing. In addition, it allowed them to determine the percentage of $P$. gingivalis in a complex sample.

Sakamoto, et al. ${ }^{49}$, in 2001 compared conventional PCR method, real-time PCR method using the LightCycler ${ }^{\mathrm{TM}}$ system, and the culture method to detect and quantify periodontopathogenic bacteria including $A$. actinomycetemcomitans, $B$. forsythus, $P$. gingivalis, $T$. denticola and $T$. socranskii in saliva and subgingival plaque. There was good agreement between the results of conventional PCR and real-time PCR methods for all saliva samples. Use of the LightCycler ${ }^{\mathrm{TM}}$ system greatly simplified the process, and was able to determine the amount of periodontopathogenic bacteria within an hour. Periodontopathogenic bacteria were more frequently detected in saliva than in subgingival plaque samples. This study suggested that saliva is equal to or better than subgingival plaque for detecting and quantifying periodontopathogenic bacteria in the oral cavity.

Kumar, et al. ${ }^{23}$, in 2003, evaluated the association of newly identified bacterial species or phylotypes with periodontitis. Targets for investigation included both uncultivated phylotypes and characterized species that were not previously thought to be associated with periodontitis. In addition, species previously strongly linked to periodontitis were included for comparison. Species-specific ribosomal 16S primers for PCR amplification were developed for detection of new species. Associations with chronic periodontitis were observed for several new species or phylotypes. Named species more commonly found in subjects with chronic periodontitis than in healthy subjects included T. denticola, Eubacterium saphenum, 
Porphyromonas endodontalis, P. gingivalis, T. forsythensis, Filifactor alocis, Prevotella denticola, Cryptobacterium curtum, Treponema medium, T. socranskii, and Actinomyces naeslundii.

Therefore, PCR has revolutionized the understanding of periodontal pathogenesis. This approach not only enables the diagnosis of putative pathogens but also contributes to the identification of new ones ${ }^{21}$. It is expected that PCR will be useful in the microbiological diagnosis of periodontal disease ${ }^{48}$.

\section{Dental caries}

The discriminative power of the arbitrarily primed PCR (AP-PCR) in differentiating between Streptococcus mutans and $S$. sobrinus species, serotypes and clones was investigated by Saarela, et al. ${ }^{45}$, in 1996. Mutans streptococcal isolates obtained from 65 individuals (1-10 isolates per individual) were AP-PCR typed separately with two random primers, OPA-05 and OPA-13. OPA-05 distinguished two main AP-PCR patterns among $S$. mutans isolates and one main pattern among $S$. sobrinus isolates, whereas OPA-13 found one main AP-PCR pattern among $S$. mutans isolates and two main patterns among $S$. sobrinus isolates. Ribotyping and AP-PCR revealed 40 and 33 different types among 81 selected isolates, respectively. The results indicated that AP-PCR has good discriminative ability in differentiating between mutans streptococcal clones and that the technique is suitable for epidemiological studies on mutans streptococci.

Igarashi, Yamamoto, Goto ${ }^{18}$, also in 1996, described the hybridization analysis with $\operatorname{dex} A$ probe and the electrophoretic profiles of dextranase for identification of mutans streptococcal species. They also designed PCR primers on the basis of dexA DNA sequence of $S$. mutans in order to develop a simple, rapid and reliable identification method of the mutans streptococcal species. Since mutans streptococci are believed to be involved in the pathogenesis of dental caries, a number of identification methods have been developed to distinguish these species in clinical specimens. These researchers reported three identification methods for the mutans streptococcal species: $\operatorname{dex} A-$ hybridization analysis, PCR analysis and electrophoretic profile of dextranase. In particular, the PCR method would satisfy the above requirements and could potentially replace conventional identification methods such as biochemical and immunological tests for identifying mutans streptococcal species.

Studying the degree of association between tactile and optical methods, Allaker, et al. ${ }^{1}$, in 1998, assessed detection of $S$. mutans with a caries detector dye and using culture and PCR techniques in teeth rendered caries free. They observed that the appropriate use of a caries indicator dye is a valuable aid in caries assessment. The dye would not lead to unnecessary tissue removal assuming that the PCR detectable $S$. mutans are viable.

Rupf, et al. ${ }^{44}$, in 1999, presented a competitive PCR method for the specific quantitative determination of S. mutans, which used a homologous DNA for internal standardization. This method enabled a rapid and exact determination of unknown amounts of $S$. mutans and provided an efficient tool for evaluating the caries risk in a patient and to monitor the efficiency of preventive and therapeutic measures.

In the next year, Igarashi, Yamamoto, Goto ${ }^{17}$ designed oligonucleotide primers based upon a comparison of the dextranase gene (des) sequences from $S$. sobrinus and $S$. mutans. The primers amplified a 1610-bp long DNA fragment on the dex gene by PCR. The pair of primers was specific to $S$. sobrinus while other members of the mutans streptococci - S. mutans, S. downei, S. cricetus, S. rattus, S. macacae and $S$. ferus - gave no PCR products. Other gram-positive oral bacteria (15 strains of 10 species of cocci and 18 strains of 12 species of rods) and gram-negative oral bacteria (3 strains of 3 species of cocci and 31 strains of 22 species of rods) also gave negative results in the PCR. The application of the PCR method to human dental plaque showed that the prevalence of $S$. sobrinus (83\%) in oral cavities was higher than currently supposed (0-50\%). These results suggested that the described PCR method is suitable for the specific detection and identification of human cariogenic bacteria, S. sobrinus and S. mutans. A simple and rapid method to detect these species in human saliva was simultaneously developed by Oho, et al. ${ }^{32}$, in 2000, using PCR. Okada, et $\mathrm{al}^{34}$, in 2002, detected these bacteria by PCR in dental plaque samples and then their presence was compared with the incidence of dental caries in 77 Japanese preschool children. The dmft (decayed, missing, filled, teeth) scores of children positive for both $S$. mutans and S. sobrinus were significantly higher than those positive for $S$. mutans alone. The results indicated that children harboring both $S$. mutans and $S$. sobrinus have a significantly higher incidence of dental caries than those with $S$. mutans alone. Galaviz, Medina, Garcia $^{10}$, in 2002, identified potentially cariogenic strains of S. mutans, using PCR in dental plaque.

Richard, et al. ${ }^{42}$, in the same year, accomplished a study with the aim of finding a reliable method for the identification of the species Lactobacillus rhamnosus among other oral lactobacilli. For this purpose, two methods were assayed to generate genomic patterns suitable for characterization at the species level, hybridization with DNA probes and PCR. The authors described a DNA probe and a specific PCR primer able to discriminate $L$. rhamnosus from other Lactobacillus species. These techniques may prove useful for identifying this species and localizing it within its ecological niche, thereby helping to elucidate the progression of the carious process.

Rupf, et al. ${ }^{43}$, in 2003, used saliva samples from 16 children with current caries activity to investigate the presence of $S$. mutans using three different PCR techniques, and the results were compared with those of selective cultivation on mitis salivarius agar with bacitracin. In order to exclude the influence of PCR inhibitors as well as inhomogeneities in the saliva samples, additional DNA preparations were carried out before PCR. Competitive PCR on the real-time instrument was found to be more rapid, comparably sensitive, but less reproducible than competitive PCR on a block cycler. In the 
same year, Toi, Bonecker, Cleaton-Jones ${ }^{61}$ determined the effectiveness of Atraumatic Restorative Treatment (ART) by using the levels of mutans streptococci and lactobacilli as markers with emphasis on the presence of $S$. mutans and S. sobrinus strains in carious lesions, and those persisting on the hard cavity wall after ART. A total of 71 mutans streptococci isolates from 31 children and 40 teeth were subcultured, biochemically characterized, and genotyped by the arbitrarily primed PCR.

PCR and RT-PCR would seem to be suitable for studying the epidemiology and relatedness of individual isolates. They may prove useful for identifying the species associated with dental caries and localizing them within their ecological niche, thereby helping to elucidate the progression of the carious process ${ }^{42}$.

\section{Endodontic infections}

Using PCR technique, Bogen, Slots ${ }^{4}$, in 1999, aimed to determine the prevalence of Porphyromonas endodontalis, $P$. gingivalis, $P$. intermedia and $P$. nigrescens in 20 closed periapical lesions associated with non-healing endodontically treated teeth which, regardless the patient symptomatology, required surgical treatment. The authors concluded that black-pigmented anaerobic rods do not seem to constitute major organisms in closed periapical lesions refractory to conventional endodontic treatment. The relatively low occurrence of black-pigmented anaerobic rods in closed periapical lesions may help to explain the relatively stable and chronic nature of the disease.

Since $P$. endodontalis has been isolated from the endodontic infections mainly in symptomatic teeth, Machado de Oliveira, et al. ${ }^{27}$, in 2000, evaluated the occurrence of $P$. endodontalis in both symptomatic and asymptomatic endodontic infections using 16S rRNA genedirected PCR. The results indicated that, although $P$. endodontalis was commonly detected in symptomatic cases, it could also be present in asymptomatic root canal infections.

Although bacteria have been the most studied etiological agent for the majority of pulpal and periradicular disease, fungi have also been associated with infected root canals. So, Baumgartner, Watts, $\mathrm{Xia}^{3}$, in 2000, evaluated the contents of infected root canals and aspirates of cellulitis/abscesses of endodontic origin for the presence of Candida albicans using PCR. The results indicate that PCR is an extremely sensitive molecular method that may be used to identify $C$. albicans directly in samples from infections of endodontic origin.

A 16S rDNA-directed PCR method was used by Siqueira Junior, et al. ${ }^{54}$, in 2001a, to assess the occurence of four black-pigmented anaerobic rods, $T$. denticola and $A$. actinomycetemcomitans in acute periradicular abscesses. The high prevalence of $P$. endodontalis, T. denticola, and $P$. gingivalis suggested that they could play an important role in the etiology of acute periradicular abscesses. These authors, in 2001, using the same methodology tried to detect the occurrence of $T$. denticola in root canals. Findings suggested that $T$. denticola could be involved in the pathogenesis of periradicular lesions of endodontic origin ${ }^{55}$.

Based on the studies above, molecular methods can be used to characterize the microflora associated with endodontic infections without the inherent biases of culture techniques $^{21}$.

\section{Oral cancer}

Kariyazono, et al. ${ }^{20}$, in 2001, reported the detection of 22q11.2 deletions using TaqMan PCR-based gene dosage analysis of patients previously diagnosed by fluorescent in situ hybridization. They performed quantitative PCR of the UFD1L gene from this region and showed a 99.7\% statistical correlation between the two methods.

Telomerase activity is associated with most malignant human tumors but is not detected in normal somatic cells with a few exceptions. Three major subunits (hTR, hTP1 and gTERT) of telomerase have been identified. To investigate the clinical implications of the mRNA detection of these components as useful diagnostic and prognostic markers in oral cancer, Lee, et al. ${ }^{24}$, in 2001, examined TA, hTR, fTP1 and hTERT mRNA expressions in 46 oral squamous cell carcinomas (OSCC) and 15 normal oral mucosal tissues from healthy volunteers using a highly sensitive TRAP assay and RT-PCR. The results suggested that the detection of hTERT expression may be another useful diagnostic marker for early detection of OSCC and to distinguish healthy tissues from neoplastically transformed ones.

Quantitative real time PCR was performed by Reis, et al. ${ }^{41}$, in 2002, on genomic DNA from 40 primary oral carcinomas and the normal adjacent tissues. The target genes ECGFB, DAI1, BIK and PDGFB and the microsatellite markers D22S274 and D22S277, mapped on 22q13, were selected according to their previous loss of heterozygosity findings in head and neck tumors. Statistically significant correlations were observed for patients with relative copy number loss of the marker D22S274 and stages T3-T4 of disease, family history of cancer, and death. Relative copy number loss involving the DIA1gene was correlated to family history of cancer, death, and consumption of alcohol. Log-rank test revealed a significant decrease in survival for patients with DIA1 gene loss. Therefore, relative copy number losses detected in these sequences may be related to disease progression and a worse prognosis in patients with oral cancer.

Davies, et al. ${ }^{7}$, also in 2002, aiming to identify the organisms involved in oral yeast carriage in patients with advanced cancer, observed that oral candidosis was a major clinical problem among these patients. The frequency of isolation of individual species by PCR was Candida albicans, 46\%; Candida glabrata, 18\%; Candida dubliniensis, 5\%; others, $<5 \%$. The study suggested that infections with the non-C. albicans species were more prevalent in this population.

Oral cancer diagnosis, prognosis, and treatment may be improved through the study and use of genetic markers 
identified both by means of immunohistochemistry, PCR and other molecular biology procedures ${ }^{30}$.

\section{DISCUSSION}

The application of molecular biology techniques has allowed the analysis of microbial diversity in environment samples. Several methods have been employed to detect putative periodontal and cariogenic pathogens in clinical samples $^{8,14-18,22,26,29,32-36,38,39,42,44,45,47-49,57-59}$.

PCR technique can advantageously substitute conventional diagnostic procedures for infections caused by different microorganisms $s^{9,29,49}$. Conventional procedures are based on infectious agent growth in culture, that can last weeks, or on detection of their presence by antibodies using a relatively insensitive method. PCR technique is much more sensitive and fast, allowing for detection of as little as 10 to $10^{2}$ bacteria per human cell. For detection of a determined infectious agent, specific primers for pathogen DNA sequences are chosen. Identification of individual strains can be done by posterior hybridization of PCR product with species-specific probes ${ }^{9}$.

In the past few years, the polymerase chain reaction (PCR) assay has been developed for detecting putative microorganisms of oral cavity. It is quick, relatively simple, and able to detect low numbers of bacterial species with a detection limit of several to $10^{2}$ cells. Further, $16 \mathrm{~S}$ ribosomal RNA has been demonstrated to be more useful for establishing the relationship of pathogens due to its high information content, conservative nature, and universal distribution ${ }^{14}$. Thus, PCR is considered suitable for detection of periodontal pathogens ${ }^{8,14,22,26,29,33,35,36,38,39,47-49,58,59}$ and cariogenic ones ${ }^{14,16-18,32,34,42,44,45,57}$, both from dental plaque $^{8,14,22,26,35,36,38,47-49,58,59}$ and from saliva ${ }^{29,42,47-49,59}$. PCR has also been used for detection of microorganisms involved with endodontic infections ${ }^{2-4,27,54,56}$, which could represent a benefit for their treatment. Studies have shown that the proportion of microorganisms in dental plaque, saliva and endodontic infection samples can be low, so that traditional culture methods can be inefficient for pathogen detection. Some reports have shown that PCR, in addition to being a rapid method, is much more sensitive than traditional culture methods for detection of putative microorganisms ${ }^{29,49}$, which could justify PCR utilization over traditional culture methods.

PCR is also a powerful tool for detecting viruses present in host cells. Using correct primer sequences, human body biopsy material can be tested for the presence of latent viral infections ${ }^{5,9,28,37,53}$. In dentistry, PCR has been used to detect human papillomavirus ${ }^{5}$ and hepatitis $\mathrm{C}$ virus ${ }^{28}$, and also in other studies that suggest virus involvement in the etiology of periodontal disease $\mathrm{e}^{37,53}$.

The most common use of PCR is to increase the amount of a particular stretch of DNA, so that it can be analyzed further. Several types of further analysis are used, such as: construction of cDNA libraries, analysis of gene transcription profiles, cloning of new genes, sequence completion of partially sequenced genes, restriction enzyme mapping, allele-specific oligonucleotide hybridization and template generation for DNA sequencing ${ }^{46,62}$. Regarding DNA sequencing, PCR has allowed genomic sequencing of various microorganisms ${ }^{9,23,62}$. In this particular, genomic sequencing of cariogenic or periodontopathogenic microorganisms represents an additional example of potential perspectives for PCR application in dentistry. Another use of PCR in dentistry has been in detection of useful markers in diagnostic and prognostic of some types of oral cancer $^{20,24,41}$. For this purpose, PCR stands out by its rapidity, ease, relatively low cost and the small quantities of DNA required for accurate analysis ${ }^{20}$.

As previously mentioned, PCR assay can be preceded by a reverse transcription when RNA is the available genetic material (RT-PCR). Reverse transcription reaction has the objective of cDNA production, so that part of this cDNA can be amplified by PCR. RT-PCR is used to analyze differential gene expression or cloned cDNAs without constructing a cDNA library. RT-PCR is more sensitive and easier to perform than other RNA analysis techniques, including Northern blots, ribonuclease protection assays, in situ hybridization, and S1 nuclease assays ${ }^{40}$. RT-PCR has also been used in dental research in order to assess the expression of mRNA for proteins involved in the development of periodontal disease $\mathrm{e}^{11,33,39}$. High sensitivity (getting enough product from small samples) and high specificity (selective amplification of only the desired product) are the hallmarks of successful PCR. Optimal RTPCR and PCR can be obtained through careful experimental design, including selecting the appropriate enzymes, designing optimal primers, using different buffers and additives, establishing cycling parameters, and preparing high quality templates ${ }^{40}$.

\section{CONCLUSIONS}

Based on the items exposed and discussed above, it is possible to conclude that:

$\S$ Among the available molecular biology techniques, two that have revolutionized nucleic acids analysis are the polymerase chain reaction (PCR) assay, which is based on the exponential amplification of a DNA fragment, and reverse transcription preceding polymerase chain reaction (RT-PCR). In the latter, RNA serves as template for cDNA production, which will have a specific sequence amplified by PCR. RTPCR makes possible, for example, the analyses of gene expression in cells and tissues.

$\S$ In dentistry, PCR and RT-PCR have been used to detect factors involved in the etiology of many diseases, such as: dental caries, periodontal disease, endodontic infections and cancer. In a comparative analysis with traditional culture methods for detecting microorganisms, these techniques show advantages because of their speed, high specificity, and high sensitivity. 


\section{RESUMO}

Várias técnicas de biologia molecular têm sido disponibilizadas nos últimos anos. Uma que revolucionou a análise de ácidos nucléicos foi a reação em cadeia da polimerase (PCR), descrita pela primeira vez em 1985. Esta técnica baseia-se na possibilidade de amplificação exponencial de fragmentos específicos de DNA, com a criação de milhões de cópias que servirão como matériaprima para diferentes tipos de análises. A PCR pode ser precedida por uma reação de transcrição reversa (RT) para a obtenção de cDNA a partir de RNA(RT-PCR), representando, por exemplo, uma possibilidade de análise de expressão gênica em células ou tecidos. As técnicas de PCR e RT-PCR têm sido utilizadas em pesquisas odontológicas como ferramentas auxiliares para nortear não só o diagnóstico como também o tratamento e prevenção de várias doenças (cárie, doença periodontal, lesões endodônticas e câncer), uma vez que se mostram vantajosas em comparação a outras técnicas tradicionais pela sua alta especificidade, alta sensibilidade e rapidez. Por se tratar de técnicas relativamente novas e não disponíveis para a maioria dos profissionais e estudantes de Odontologia, o objetivo do presente trabalho é apresentar detalhes da PCR e da RT-PCR, bem como trabalhos da literatura em que ambas foram utilizadas.

UNITERMOS: Cárie dentária; Periodontite; Doenças da polpa dentária; Câncer bucal.

\section{ACKNOWLEDGEMENTS}

The authors would like to express their gratitude to Thiago José Dionísio, Ricardo Garcia Mureb Jacob and Rafael Luis Sakai for excellent technical assistance.

\section{REFERENCES}

1- Allaker RP, Seddon SV, Tredwin C, Lynch E. Detection of Streptococcus mutans by PCR amplification of the spaP gene in teeth rendered caries free. J Dent 1998 Jul/Aug; 26(5-6): 443-5.

2- Bate AL, Ma JK, Pitt Ford TR. Detection of bacterial virulence genes associated with infective endocarditis in infected root canals. Int Endod J 2000 May; 33(3): 194-203.

3- Baumgartner JC, Watts CM, Xia T. Occurrence of Candida albicans in infections of endodontic origin. J Endod, 2000 Dec; 26(12): 695-8.

4- Bogen G, Slots J. Black-pigmented anaerobic rods in closed periapical lesions. Int Endod J 1999 May; 32(3): 204-10.

5- Chen PC, Duo C, Pan CC, Chou MY. Risk of oral cancer associated with human papillomavirus infection, betel quid chewing, and cigarette smoking in Taiwan: an integrated molecular and epidemiological study of 58 cases. J Oral Pathol Med 2002 July; 31(6): 317-22.
6- Conrads G. DNA probes and primers in dental practice. Clin Infect Dis 2002 Sept; 35(Suppl1): S72-7.

7- Davies AN, Brailsford S, Broadley K, Beighton D. Oral yeast carriage in patients with advanced cancer. Oral Microbiol Immunol 2002; 17: 79-84.

8- Doungudomdacha S, Rawlinson A, Douglas CWI. Enumeration of Porphyromonas gingivalis, Prevotella intermedia and Actinobacillus actinomycetemcomitans in subgingival plaque samples by a quantitative-competitive PCR method. J Med Microbiol 2000 Oct; 49(10): 861-74.

9- Farah SB. DNA: segredos \& mistérios. São Paulo: Sarvier; 2000. 10) Galaviz LAA, Medina MDCA, Garcia ICE. Detection of potentially cariogenic strains of Streptococcus mutans using the polymerase chain reaction. J Clin Pediatr Dent 2002; 27(1): 4751.

11- Garlet GP, Martins Junior W, Ferreira BR, Milanezi CM, Silva JS. Patterns of chemokines and chemokine receptors expression in different forms of human periodontal disease. $\mathrm{J}$ Periodont Res 2003; 38: 210-7.

12- Greene AS. Life and death in the microcirculation: a role for angiotensin II. Microcirculation 1998; 5(2-3): 101-7.

13- Hart TC, Marazita ML, Wright JT. The impact of molecular genetics on oral health paradigms. Crit Rev Oral Biol Med 2000; 11(1): 26-56.

14- Hayashi F, Okada M, Zhong X, Miura K. PCR detection of Capnocytophaga species in dental plaque samples from children aged 2 to 12 years. Microbiol Immunol 2001; 45(1): 17-22.

15)- Ida H, Igarashi T, Yamamoto A, Goto N, Sasa R. A DNA probe specific to Streptococcus sobrinus. Oral Microbiol Immunol 1999 Aug; 14(4): 233-7.

16- Igarashi T, Yano Y, Yamamoto A, Sasa R, Goto N. Identification of Streptococcus salivarius by PCR and DNA probe. Lett Appl Microbiol 2001 June; 32(6): 394-7.

17- Igarashi T, Yamamoto A, Goto N. PCR for detection and identification of Streptococcus sobrinus. J Med Microbiol 2000 Dec; 49(12): 1069-74.

18- Igarashi T, Yamamoto A, Goto N. Rapid identification of mutans streptococcal species. Microbiol Immunol 1996; 40(11): 867-71.

19- Jordan RCK, Daniels TE, Greenspan JS, Regezi JA. Advanced diagnostic methods in oral and maxillofacial pathology. Part I: molecular methods. Oral Maxillofac Pathol 2001 Dec; 92(6): 65069.

20- Kariyazono H, Ohno T, Ihara K, Igareshi H, Joh-o K, Ishikawa $\mathrm{S}$ et al. Rapid detection of the 22q11.2 deletion with quantitative real-time PCR. Mol Cell Probes 2001 Apr; 15(2): 71-3.

21- Kim Y, Flynn TR, Donoff RB, Wong DTW, Todd R. The gene: the polymerase chain reaction and its clinical application. J Oral Maxillofac Surg 2002; 60: 808-15. 
22- Kimura S, Ooshima T, Takiguchi M, Sasaki Y, Amano A, Morisaki I, et al. Periodontopathic bacterial infection in childhood. J Periodontol 2002 Jan; 73(1): 20-6.

23- Kumar PS, Griffen AL, Barton JA, Paster BJ, Moeschberger ML, Leys EJ. New bacterial species associated with chronic periodontitis. J Dent Res 2003; 82(5): 338-44.

24- Lee BK, Diebel E, Neukam FW, Wiltfang J, Ries J. Diagnostic and prognostic relevance of expression of human telomerase subunits in oral cancer. Int J Oncol 2001 Nov; 19(5): 1063-8.

25- Linderman JR, Greene AS. Distribution of agiotensin II receptor expression in the microcirculation of striated muscle. Microcirculation 2001 Aug; 8(4): 275-81.

26- Lyons SR, Griffen AL, Leys EJ. Quantitative real-time PCR for Porphyromonas gingivalis and total bacteria. J Clin Microbiol 2000 June; 38(6): 2362-5.

27- Machado de Oliveira JC, Siqueira Junior JF, Alves GB, Hirata $\mathrm{R} \mathrm{Jr}$, Andrade AF. Detection of Porphyromonas endodontalis in infected root canals by $16 \mathrm{~S}$ rRNA gene-directed polymerase chain reaction. J Endod 2000 Dec; 26(12): 729-32.

28- Maticic M, Poljak M, Kramar B, Seme K, Brinovec V, MeglicVolkar J, et al. Detection of hepatitis C virus RNA from gingival crevicular fluid and its relation to virus presence in saliva. $\mathrm{J}$ Periodontol 2001 Jan; 72(1): 11-6.

29- Mättö J, Saarela M, Alaluusua S, Oja V, Jousimies-Somer H, Asikainen S. Detection of Porphyromonas gingivalis from saliva by PCR by using a simple sample-processing method. J Clin Microbiol 1998 Jan; 36(1): 157-60.

30- Murdoch-Kinch CA. Oral medicine: advances in diagnostic procedures. J Calif Dent Assoc 1999 Oct; 27(10): 773-84.

31- Nora EH, Munzenmaier DH, Hansen-Smith FM, Lombard $\mathrm{JH}$, Greene AS. Localization of the ANG II type 2 receptor in the microcirculation of skeletal muscle. Am J Physiol 1998 Oct; 275 (4 Pt 2): H1395-403.

32- Oho T, Yamashita Y, Shimazaki Y, Kushiyama M, Koga T. Simple and rapid detection of Streptococcus mutans and Streptococcus sobrinus in human saliva by polymerase chain reaction. Oral Microbiol Immunol 2000 Aug; 15(4): 258-62.

33- Okada H, Murakami S, Kitamura M, Nozaki T, Kusumoto Y, Hirano H, et al. Diagnostic strategies of periodontitis based on the molecular mechanisms of periodontal tissue destruction. Oral Disease 1996 Mar; 2(1): 87-95.

34- Okada M, Soda Y, Hayashi F, Doi T, Suzuki J, Miura K, et al. PCR detection of Streptococcus mutans and S. sobrinus in dental plaque samples from Japanese pre-school children. J Med Microbiol 2002 May; 51(5): 443-7.

35- Okada M, Hayashi F, Nagasaka N. Detection of Actinobacillus actinomycetemcomitans and Porphyromonas gingivalis in dental plaque samples from children 2 to 12 years of age. J Clin Periodontol 2000 Oct; 27(10): 763-8.
36- Okada M, Hayashi F, Nagasaka N. PCR detection of 5 putative periodontal pathogens in dental plaque samples from children 2 to 12 years of age. J Clin Periodontol 2001 Jun; 28(6): 576-82.

37- Parra B, Slots J. Detection of human viruses in periodontal pockets using polymerase chain reaction. Oral Microbiol Immunol 1996 Oct; 11(5): 289-93.

38- Paster BJ, Boches SK, Galvin JL, Ericson RE, Lau CN, Levanos VA, et al. Bacterial diversity in human subgingival plaque. J Bacteriol 2001 Jun; 183(12): 3770-83.

39- Preshaw PM, Geatch DR, Lauffart B, Jeffcoat MK, Taylor JJ, Heasman PA. Longitudinal changes in TCRB variable gene expression and markers of gingival inflammation in experimental gingivitis. J Clin Periodontol 1998 Oct; 25(10): 774-80.

40- PCR/RT-PCR applications guide. Available at: <http:// www.invitrogen.com/Content/TechOnline/molecular_biology/ manuals_pps/pcrtechguide.pdf>. Acess on: Nov 192002.

41- Reis PP, Rogatto SR, Kowalski LP, Nishimoto IN, Montovani FC, Corpus G, et al. Quantitative real-time PCR identifies a critical region of deletion on 22q13 related to prognosis in oral cancer. Oncogene 2002 Sept; 21(42): 6480-7.

42- Richard B, Groisillier A, Badet C, Dorignac G, Lonvaud-Funel A. Identification of salivary Lactobacillus rhamnosus species by DNA profiling and a specific probe. Res Microbiol 2001 Mar; 152(2): 157-65.

43- Rupf S, Merte K, Kneist S, Al-Robaly S, Eschrich K. Comparison of different techniques of quantitative PCR for determination of Streptococcus mutans counts in saliva samples. Oral Microbiol Immunol 2003; 18: 50-3.

44- Rupf S, Kneist S, Merte K, Eschrich K. Quantitative determination of Streptococcus mutans by using competitive polymerase chain reaction. Eur J Oral Sci 1999 Apr; 107(2): 7581.

45- Saarela M, Hannula J, Matto J, Asikainen S, Alaluusua S. Typing of mutans streptococci by arbitrarily primed polymerase chain reaction. Arch Oral Biol 1996 Aug/Sept; 41(8-9): 821-6.

46- Saiki RK, Stephen S, Fallona F, Mullis KB, Horn GT, Erlich $\mathrm{HA}$, et al. Enzymatic amplification of b-globin genomic sequences and restriction site analysis for diagnosis of sickle cell anemia. Science 1985 Dec; 230(4732): 1350-4.

47- Sakamoto M, Umeda M, Ishikawa I, Benno Y. Comparison of the oral bacterial flora in saliva from a healthy subject and two periodontitis patients by sequence analysis of $16 \mathrm{~S}$ rDNA libraries. Microbiol Immunol 2000; 44(8): 643-52.

48- Sakamoto M, Takeuchi Y, Umeda M, Ishikawa I, Benno Y, Nakase T. Detection of Treponema socranskii associated with human periodontitis by PCR. Microbiol Immunol 1999; 43(5): 485-90.

49- Sakamoto M, Takeuchi Y, Umeda M, Ishikawa I, Benno Y. Rapid detection and quantification of five periodontopathic bacteria by real time PCR. Microbiol Immunol 2001; 45(1): 39-44. 
50- Santos CF, Oliveira EB, Salgado MCO, Greene AS. Molecular cloning and sequencing of the $\mathrm{c}$ DNA for rat mesenteric arterial bed elastas-2, an angiotensin II-forming enzyme. J Cardiovasc Pharmacol 2002 May; 39(5): 628-35.

51- Santos CF, Caprio MAV, Oliveira EB, Salgado MCO, Schippers DN, Munzenmaier DH, Greene AS. Functional role, cellular source and tissue distribution of rat elastase-2, an angiotensin II-forming enzyme. Am J Physiol (Heart Circ Physiol) 2003 Aug; 285(2): H775-83.

52- Saygun I, Sahin S, Ozdemir A, Kurtis B, Yapar M, Kubar A, et al. Detection of human viruses in patients with chronic periodontitis and the relationship between viruses and clinical parameters. J Periodontol 2002 Dec; 73(12): 1437-43.

53- Shelburne CE, Gleason RM, Germaine GR, Wolff LF, Mullally $\mathrm{BH}$, Coulter WA, et al. Quantitative reverse transcription polymerase chain reaction analysis of Porphyromonas gingivalis gene expression in vivo. J Microbiol Meth 2002 Apr; 49(2): 14756 .

54- Siqueira Junior JF, Rocas IN, Oliveira JC, Santos KR. Detection of putative oral pathogens in acute periradicular abscesses by $16 \mathrm{~S}$ rDNA-directed polymerase chain reaction. J Endod 2001a Mar; 27(3): 164-7.

55- Siqueira Junior JF, Rocas IN, Oliveira JC, Santos KR. Polymerase chain reaction detection of Treponema denticola in endodontic infections within root canals. Int. Endod J 2001b Jun; 34(4): 2804.

56- Siqueira Junior JF, Rocas IN, Oliveira JC. Prevalence of Prevotella intermedia and Prevotella nigrescens in infected root canals from a Brazilian population. Aust Endod J 2000 Dec; 26(3): $110-2$

57- Soet JJ de, Bokhout B, Buijs JF, van Loveren C, Graaff J de, Prahl-Andersen B. Transmission of mutans streptococci between mothers and children with cleft lip and/or palate. Cleft Palate Craniofac 1998 Sept; 35(5): 460-4.

58- Suzuki N, Nakano Y, Yoshida Y, Ikeda D, Koga T, et al. Identification of Actinobacillus actinomycetemcomitans serotypes by multiplex PCR. J Clin Microbiol 2001 May; 39(5): 2002-5.

59- Takeuchi Y, Makoto U, Sakamoto M, Benno Y, Huang Y, Ishikawa I Treponema socranskii, Treponema denticola, and Porphyromonas gingivalis are associated with severity of periodontal tissue destruction. J Periodontol 2001 Oct; 72(10): 1354-63.

60- Telles PDS, Hanks CT, Machado MAAM, Nor JE. Lipoteichoic acid up-regulates VEGF expression in macrophages and pulp cells. J Dent Res. 2003 June;82(6):466-70.

61- Toi CS, Bönecker M, Cleaton-Jones PE. Mutans streptococci strains prevalence before and after cavity preparation during Atraumatic Restorative Treatment. Oral Microbiol Immunol 2003; 18: $160-4$.

62- Wright PA, Wynford-Thomas D. The polymerase chain reaction: miracle or mirage? A critical review of its uses and limitations in diagnosis and research. J Pathol, 1990 Oct; 162(2): 99-117.
Correspondence Address:

Carlos Ferreira Santos

Al. Octávio Pinheiro Brisolla, 9-75

Bauru-SP

17012-901 Brazil

Phone \#: 55142358276 Fax \#: 55142234679

E-mail: cebola@usp.br 